Ginkgo 


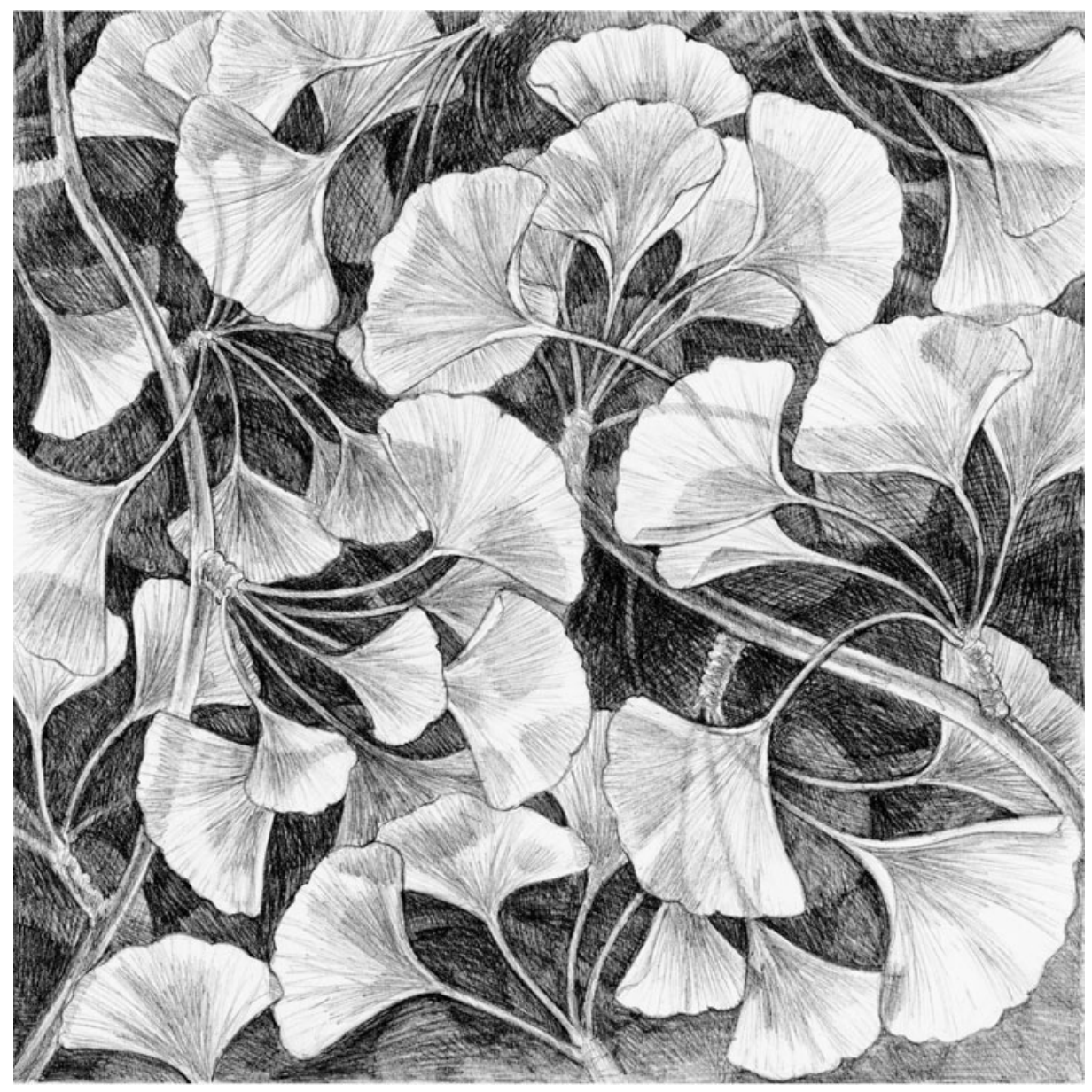

Yale UnIVERSITY PRESS

New Haven and London 


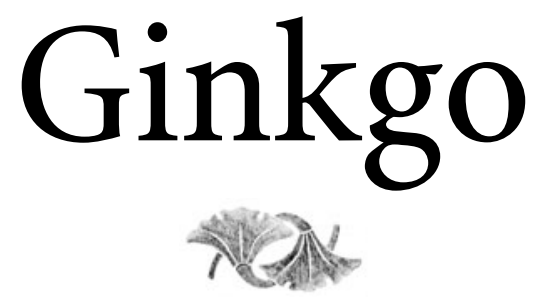

THE TREE THAT TIME FORGOT

\section{Peter Crane}

WITH A FOREWORD BY PETER RAVEN 
Published with assistance from the foundation established in memory of Philip Hamilton McMillan of the Class of 1894, Yale College.

Copyright $\odot 2013$ by Peter Crane. All rights reserved. This book may not be reproduced, in whole or in part, including illustrations, in any form (beyond that copying permitted by Sections 107 and 108 of the U.S. Copyright Law and except by reviewers for the public press), without written permission from the publishers.

Yale University Press books may be purchased in quantity for educational, business, or promotional use. For information, please e-mail sales.press@yale.edu (U.S. office) or sales@yaleup.co.uk (U.K. office).

Designed by Nancy Ovedovitz and set in Minion type by Tseng Information Systems, Inc. Printed in the United States of America.

\section{Library of Congress Cataloging-in-Publication Data}

Crane, Peter R.

Ginkgo : the tree that time forgot / Peter Crane.

p. $\mathrm{cm}$.

Includes bibliographical references and index. ISBN 978-0-300-18751-9 (cloth : alk. paper)

$$
\begin{gathered}
\text { 1. Ginkgo. I. Title. } \\
\text { QK494.5.G48C73 } 2013 \\
585^{\prime} .7-\mathrm{dc} 23 \quad 2012032831
\end{gathered}
$$

A catalogue record for this book is available from the British Library.

This paper meets the requirements of ANSI/NISO Z39.48-1992 (Permanence of Paper). 
FOR EMILY AND SAM

with hope for their generation's wider view of the world 


\section{Ginkgo biloba}

Dieses Baum's Blatt, der von Osten

Meinem Garten anvertraut,

Giebt geheimen Sinn zu kosten,

Wie's den Wissenden erbaut.

Ist es ein lebendig Wesen?

Das sich in sich selbst getrennt;

Sind es zwey? die sich erlesen,

Dass man sie als eines kennt.

Solche Frage zu erwiedern

Fand ich wohl den rechten Sinn;

Fühlst du nicht an meinen Liedern,

Dass ich Eins und doppelt bin?

-Johann Wolfgang von Goethe, September 15, 1815 
Ginkgo biloba

This tree's leaf which from the Orient

Is entrusted to my garden

Lets us savor a secret meaning

As to how it edifies the learned man.

Is it one living being?

That divides itself into itself

Are there two who have chosen each other,

So that they are known as one?

To reply to such a question

I found, I think, the condign sense.

Do you not feel that in my poems

I am single and twofold?

-English translation by Kenneth Northcott, 2006 
This page intentionally left blank 